\title{
Lateral
}

JOURNAL OFTHE CULTURALSTUDIESASSOCIATION

Patrick ffrench, "Review of 'The Essentialist Villain: On Leo Bersani' by Mikko Tuhkanen (State University of New York Press, 2018)," Lateral 7.2(2018).

https://doi.org/10.25158/L7.2.20

This content is licensed under a Creative Commons Attribution 4.0 International License. Copyright is retained by authors.

Book Reviews

Issue 7.2 (Fall 2018)

\section{Review of The Essentialist Villain: On Leo Bersaniby Mikko Tuhkanen (State University of New York Press)}

\section{Patrick ffrench}

\begin{abstract}
Mikko Tuhkanen's provocative and comprehensive study of the work of Leo Bersani deserves the status of a decisive and paradigm-shifting event in the field of critical theory. Bersani's work, which has evolved over a period of over fifty years, emerges as something like a Trojan Horse within the hegemonic camp of critical theory for which only difference and alterity are positive and mobile. Tukhanen draws out and in so doing sharpens Bersani's consistent call for a radical reassessment of precisely those concepts and values connoted as negative, redundant, static, or even politically and ethically dangerous in the broad orthodoxy of critical theory: sameness, essence, narcissism, the speculative. Tuhkanen shows adeptly, through a series of engagements with Bersani's preferred critical objects-Baudelaire, Freud, Proust, Beckett, Jean Laplanche, to name only those most prominent-how Bersani, the "essentialist villain," has wielded the critical armory of essence against, but also within, the domain of what is construed as a pervasive ontology of loss, lack, and trauma.
\end{abstract}

The Essentialist Villain: On Leo Bersani. By Mikko Tuhkanen. New York: State University of New York Press, 2018. Pp. 248 (paper). ISBN 978-0-8166-9530-0. US List $\$ 90.00$.

Mikko Tuhkanen's provocative and comprehensive study of the work of Leo Bersani deserves the status of a decisive and paradigm-shifting event in the field of critical theory. Bersani's work, which has evolved over a period of over fifty years, emerges as something like a Trojan Horse within the camp of critical theory for which only difference and alterity are positive and mobile. Tukhanen draws out and in so doing sharpens Bersani's consistent call for a radical re-assessment of precisely those concepts and values connoted as negative, redundant, static, or even politically and ethically dangerous in the broad orthodoxy of critical theory: sameness, essence, narcissism, the speculative.

Tuhkanen shows adeptly, through a series of engagements with Bersani's preferred critical objects-Charles Baudelaire, Sigmund Freud, Marcel Proust, Samuel Beckett, Jean Laplanche, to name only those most prominent-how Bersani, the "essentialist villain," has wielded the critical armory of essence against, but also within, the domain of what is construed as a pervasive ontology of loss, lack, and trauma. This also entails a frontal offensive on the correlative ally of this ontology in theories and cultures of redemption (Tuhkanen clarifies Bersani's considered rejection of the work of Walter Benjamin, for example). Sameness, elaborated independently of its negative place in the schema of fascinating and paralyzing otherness, turns out to be richer, deeper, and more varied than one might have suspected. A particularly productive seam is found, via Proust, Beckett, Maurice Blanchot, and Gilles Deleuze, in the Leibnizian monad, an "alternate philosophical genealogy" (30) out of which Tuhkanen pulls the felicitous term "homonadology," wherein "monadic sameness," rather than relational difference, is promoted as an "ontological principle" (43). 
The challenge Bersani has (successfully) confronted, in Tuhkanen's account, is to have wrested a kind of essence from the mold of the broadly psychoanalytic framework in which being is constitutively lacking. Drawing some impetus from Deleuze and Félix Guattari (whose parallel reconfiguration of desire perhaps deserved greater attention), Tuhkanen's Bersani has developed a theory of desire based not on lack or on the scene of the subject in thrall to the other. Instead, desire emerges as an appetite for variegated sameness which, severed from the fraught psychology of intersubjectivity, is colored by the somewhat indifferent appreciation of Baudelairean correspondances, an example recurrently evoked by Tuhkanen. Indeed the serial patterns and sensory echoes imagined in Baudelaire's sonnet promote an aesthetics of desire. Bersani's desire is provocatively non-sexual; although Bersani appears as arguably the critical/literary theorist who has most consistently and profoundly engaged (as one engages an adversary) with the Freudian version of the human psyche, the ultimate strategy, as it comes into view with hindsight, has been to de-couple desire and sex, to de-sexualize desire.

Sexuality, disastrously enmeshed with the experience and the appeal of ontological shattering-of oneself or of the other-appears as something not at all to do with desire or pleasure, but more to do with psychology. The de-sexualization of desire in Bersani's work is part of a long-wavelength strategy to extricate desire from the paranoid psychology of persons, from the suspicion, as Bersani puts it in a chapter of The Culture of Redemption on Proust and Melanie Klein, that the other harbors an "evil intention" in respect to me (Harvard University Press, 1990, p. 23). Bersani seeks to free desire from the trap of the subject, so to speak.

Tuhkanen points out that in this move outside the subject Bersani is aligned with the later Michel Foucault, though not, as the latter had proposed in The Will to Knowledge, in the abdication of desire as a functional concept fit to the task. A different way of putting this, and one which starts to give a sharper picture of Bersani's overall game-plan, is to say that his engagement with psychoanalysis, via Freud but also especially via Jean Laplanche, has informed a rigorously pessimistic assessment of the reality of human intersubjective relations, as paranoid, as masochistic-sadistic, as driven by the urge to repeat an experience of annihilation, and as driven by hatred toward the world. This is the descriptive base of Bersani's ethos. Prescriptively, or ethically, the other side of Bersani's work lies in the careful yet enthused identification of the kinds of literary and cultural work that might allow us to glimpse another form of being. This is the true worth of critical theory: the balance between an analytic understanding of how things are and the imaginative postulation of how they may be otherwise. Tuhkanen situates Bersani precisely at that line.

For readers less familiar with Bersani's work, The Essential Villain will be an excellent companion to the work itself. Those whose contact with Bersani stems out of queer theory will find an extension of Tuhkanen's edited volume Leo Bersani: Queer Theory and Beyond (SUNY Press, 2014) and a deeper exploration of the grounding of Bersani's perspectives on sexuality in his literary criticism. For readers with an already advanced familiarity with the work, perhaps the most salient aspect will be Tuhkanen's widening of its philosophical implications. The final chapter, "Narcissus, a Cosmology" provides a good example of how Tuhkanen moves narcissism out from the restricted place it has within psychoanalytic discourse to "erode the anthropocentric frame" (167). In a brilliant encapsulation of the prescriptive thrust of Bersani's work as a whole, Tuhknanen writes of Bersani's wish for us to "unlearn [...] the onto-ethical habits affirmed by the psychoanalytic subject," and to heed the call of the "ahuman" (167-68). This is but one example of a critical ethos of generosity which imbues the book as a whole; Tuhkanen thinks with Bersani, alongside him, and enjoins his readers to do the same. 


\section{Patrick ffrench}

Patrick ffrench is Professor of French at King's College, London. He is the author of The Time of Theory: A History of Tel Quel (Oxford University Press, 1996), The Cut: Reading Bataille's Histoire de l'oeil (British Academy, 2000), After Bataille: Sacrifice, Exposure, Community (Legenda, 2007) and Thinking Cinema with Proust (Legenda, 2018), and joint editor of The Tel Quel Reader (Routledge, 1998).

\section{(c) (1)}

This work is licensed under a Creative Commons Attribution 4.0 International (CC BY) License, unless otherwise noted. ISSN 2469-4053 